\title{
MPRA
}

Munich Personal RePEc Archive

\section{Mahatma Gandhi and the Prisoner's Dilemma: Strategic Civil Disobedience and Great Britain's Great Loss of Empire in India}

Siddiky, Chowdhury Irad Ahmed

2 May 2005

Online at https://mpra.ub.uni-muenchen.de/147/

MPRA Paper No. 147, posted 06 Oct 2006 UTC 


\title{
Mahatma Gandhi and the Prisoner's Dilemma: Strategic Civil Disobedience and Great Britain's Great Loss of Empire in India ${ }^{1}$
}

\author{
Chowdhury Irad Ahmed Siddiky ${ }^{2}$
}

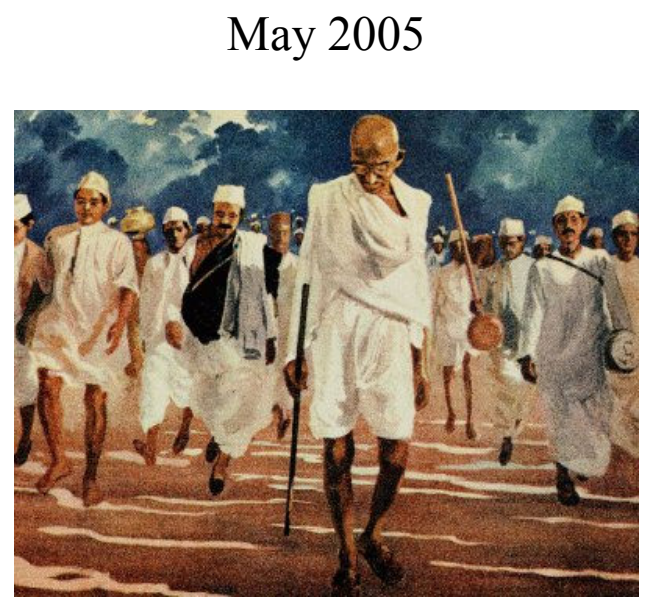

\begin{abstract}
This paper examines the relationship between statutory monopoly and collective action as a multi-person assurance game culminating in an end to British Empire in India. In a simple theoretical model, it is demonstrated whether or not a collective good enjoys (or is perceived to enjoy) pure jointness of production and why the evolutionary stable strategy of non-violence was supposed to work on the principle that the coordinated reaction of a ethnically differentiated religious crowd to a conflict between two parties (of colonizer and colonized) over confiscatory salt taxation would significantly affect its course. Following Mancur Olson (1965) and Dennis Chong (1991), a model of strategic civil disobedience is created which is used to demonstrate how collective action can be used to produce an all-or-nothing public good to achieve economic and political independence.
\end{abstract}

JEL Classification Code: H73, P16, C72, N45

Key Words: confiscatory taxation, multi-person assurance game, strategic civil disobedience.

\footnotetext{
${ }^{1}$ The political geography of "India" in this paper implies pre-partitioned India prior to her independence in 1947, which includes present day nation-states of Pakistan and Bangladesh.

${ }^{2}$ School of Law, University of Warwick. Email: Csiddiky@att.net

This paper is dedicated to the memory of courage and conviction of the people of undivided India.
} 


\section{Introduction:}

"Force cannot, like opinion, endure for long unless the tyrant extends his empire far enough afield to hide from the people, whom he divides and rules, the secret that real power lies not with the oppressors but with the oppressed." - Marquis de Condorcet ${ }^{3}$ (1745-1794).

Wwentieth-Century India lived under the kind of colonial administration that
James Madison and Thomas Jefferson had rejected ${ }^{4}$ - the kind that would have made John Adams angry ${ }^{5}$. And it did anger a great many Indians ${ }^{6}$. To the British, the Indian economy existed for the enrichment of Great Britain. Industry was for the profit of the English Midlands. Indian salt was to be managed for the benefit of Cheshire. India was an extractive state under British colonial rule that was not able to invest more in physical and human capital and use these factors efficiently to achieve a greater level of income. (e.g., Acemoglu, Johnson and Robinson, 2001; Acemoglu and Robinson, 2002; Banerjee and Iyer, 2002; Engerman and Sokoloff, 1997; 2000; 2002). History is nothing but an artificial extension of social memory ${ }^{7}$. In the view of that memory based model of bounded rationality (e.g. Mullainathan, 2002) and the new institutionalist view of history (e.g. North, 1990), history is crucial because history shapes institutions and institutions shape the economy. This proposition is further fortified by La Porta et al (1998; 1999; and 2000) who argued that the experience of colonization can have permanently lasting effect on the legal system of any country and through that on that country's economic performance.

\footnotetext{
${ }^{3}$ Condorcet, J.A (1795) Sketch for a History for the Progress of the Human Mind. Connecticut: Hyperion Press, 1979.

${ }^{4}$ Bernard Bailyn (1967) The Ideological Origins of the American Revolution. Cambridge, MA: Harvard University Press.

${ }^{5}$ Gordon S. Wood (1992) The Radicalism of the American Revolution. New York: Alfred A. Knopf.

${ }^{6}$ Getz, Marshall J. (2002) Subhas Chandra Bose: A Biography. North Carolina: McFarland \& Company.

${ }^{7}$ Becker, Carl (1931) Annual address of the president of the American Historical Association, delivered at Minneapolis. December 29, 1931. Reprinted in the American Historical Review, Volume 37(2), p. 221-236
} 
Individuals have only imperfect control over their memory. They are not able to learn everything that they would like to, mainly because it is too difficult for them. It is only possible to integrate new knowledge into one's memory by applying sufficient effort, time and resources. Unlearning various practices enforced by habits formed under colonial institutions, i.e. removing information from one's memory on colonial ways of organizing economic activities is more difficult to achieve. It is, for example, impossible to forget the information that the price of salt was fixed so artificially high by the colonial authorities that smuggling was profitable and this was often the only way many families could obtain the salt that they needed. One would be better off not knowing that smuggling was the only means for obtaining salt for their most basic consumption, but one could not choose to forget such utility enhancing information given their colonial circumstances. This "retention effect" suggests that there is a fundamental asymmetry between learning and unlearning.

Moreover, making an effort to get rid of a piece of information stored in our memory tends to have a counterproductive effect: it is rendered more vivid and therewith stored more effectively in our memory. For example, parents who constantly advise their children not to drink alcohol, to take drugs or engage in sex, often make it more difficult for the children not to think of it. This "imprinting effect" produces higher transaction costs in principal-agent relationships. Similar counterproductive effects can also be found in the colonial political economy where the colonized as dependents (like children) of the colonizer as the authority (like a parent) can retain as "imprint," the activities that were prohibited. These retained psychological "imprints" of prohibitions could later be transformed into non-violent forms of subversive collective action against the authoritarian colonial regime, as demonstrated by Mahatma Gandhi; where a colonial 
government that strictly prohibited making salt from the sea by its alien subjects, often made it more difficult for them not to think of doing so, thereby creating an "imprinting effect" that had produced very high transaction costs in the principal-agent relationship between the colonizer and the colonized, ultimately costing the British Empire in India its very existence.

Impossibility to forget may, given a history of imperialism, help people to behave rationally in the long run. In that sense, the failure to forget may in some respects be evolutionarily advantageous. If history is any evolutionary indicator of path dependence, then failure to forget the economic consequences of imperialism yielded strategic civil disobedience and eventually national independence. Non-forgetting is an instance of bounded rationality. (Simon 1957, 1982; Selten and Tietz 1980.)

\section{Salt and the Rational Fools ${ }^{8}$ : Imperial Confiscatory Taxation and Indian Strategic Civil Disobedience - A New Behavioral Economic History}

Salt is essential to human life as it regulates the amount of liquid that can be held in the body. Without it people dehydrate. It is impossible to know just how many people died as a result of the exorbitant taxing and pricing of salt. As well as dehydration, salt deficiency contributes to people's inability to recover from many other diseases. Many deaths caused or aggravated by lack of salt would not be recorded as such. Although there is not a reliable estimate of how much salt an average Indian family would need, the estimates of what Indian families were able to afford, even in times without famine, were way below the minimum the British recommended for their own soldiers. This is evident from testimony of doctors working in India sending reports to Britain protesting at the

\footnotetext{
${ }^{8}$ Sen, Amartya, (1976-77), "Rational Fools: A Critique of the Behavioural Foundations of Economic Theory," Philosophy and Public Affairs, No. 6, 1976-7, pp. 87-109
} 
salt deficiency of many Indian people. ${ }^{9}$ The price of salt was fixed so artificially high that smuggling was profitable and this was often the only way many families could obtain the salt that they needed.

Before the British created artificial trade barriers for confiscatory salt taxation, India had affordable, readily available salt. ${ }^{10}$ While it has huge salt-less regions, with natural salt fields on both its coasts and huge rock salt deposits and salt lakes in between, India had an ancient tradition of salt making and trading. Although the extensive rock salt deposits in Punjab are unusually pure, strictly religious Hindus have always had a distrust of rock salt and even salt made from boiling. Indians have always preferred solarevaporated sea salt not only for religious reasons but because it was more accessible. On the west coast, by what is now the Pakistani border, and on the east coast near Calcutta, river estuaries spread out into wetlands and marshes where the sun evaporates seawater, leaving crusts of salt. ${ }^{11}$

On the east coast is a salt-producing area known as Orissa, with a prefect natural sea salt zone along a tract that is 320 miles long and ten to sixty miles deep. The salt beds, called khalaris, are flooded in two spring tides, which saturate the soil with salt as the water evaporates. Salt made from natural solar evaporation was called karatach. ${ }^{12}$ A second salt, panga, was produced by mixing salty soil in seawater and boiling it. The salt was a permanently renewed resource, which rendered this stretch of land not only ideal for salt making but useless for anything else. In Orissa, the poorest of peasants could make salt on the khalari to use or to sell. The salt makers would clear the field, the

\footnotetext{
9 Roy, Moxham (2001) The Great Hedge of India. London: Constable.

10 Agarwal, S.C. (1976) The Salt Industry in India. New Delhi: Government of India Press. 11 Ibid.

${ }^{12}$ Choudhury, Sadananda (1979) The Economic History of Colonialism: A History of British Salt Policy in Orissa. New Delhi: Inter-India Publications.
} 
khalari, of all vegetation, grass, and roots to a depth of a few inches and then pile the waste in dikes around the edges. ${ }^{13}$

They built sluices to let in saltwater during high tide. Salt was absorbed into the earth and then more saltwater taken in with the spring tides. The additional seawater combined with the salty soil to produce concentrated brine, which they put in oblong pots, about 200 of which were cemented together by mud in a dome-shaped kiln. The salt makers placed vents at the north and south ends of each kiln so that fire would be fanned by prevailing breezes. As the brine in the pots evaporated, workers called malangis added more brine, one ladle at a time, until each pot was about three-quarters full of salt crystals. The salt, which dried in piles in the open air and which the malangis then covered with reeds, was noted for its whiteness and was considered by many to be the best salt in India, yet it was also inexpensive. ${ }^{14}$

This panga salt had an eager market in the neighbouring provinces to the West, shipped on the River Mahanandi and its tributaries. Merchants came to Orissa to buy salt or barter with products such as cotton, opium, marijuana, and grains, carried by oxcart from central India.

Even the British in India traded in Orissa salt. ${ }^{15}$ They needed large quantities of salt for the manufacture of munitions for their eighteenth-century wars with the French, and a significant part of the salt for their gunpowder came from Orissa.

Most of India, since ancient times, had a history of modest salt taxes. ${ }^{16}$ In Orissa, the Maratha, the ruling caste of much of pre-British India, levied a small tax on salt

\footnotetext{
${ }^{13}$ Ibid.

${ }^{14}$ Ibid.

${ }^{15}$ Calvert, Albert F. (1919) Salt and the Salt Industry. London: Sir Isaac Pitman \& Sons.

${ }^{16}$ Choudhury, Sadananda (1979) The Economic History of Colonialism: A History of British Salt Policy in Orissa. New Delhi: Inter-India Publications.
} 
transported commercially in the province. The trade was so extensive that they could earn a substantial profit on this moderate tax and avoid a higher one that would damage the competitive price of Orissa salt. In return for this source of revenue, they looked after the promotion and prosperity of the salt trade. The Maratha rulers' attitude towards Orissa was reminiscent of a Chinese proverb: "Governing a state is like cooking a small fish. It has to be done with a very light touch."17

The British practiced this light touch neither in governance nor in cooking. In the late eighteenth-century, Cheshire was increasing its salt production and aggressively hunting overseas markets. The empire was expected to provide these markets. Yet Liverpool salt could not compete with the price and quality of Orissa salt. ${ }^{18}$

In 1790, when the British requested permission to buy all the salt made in Orissa, the Maratha governor of Orissa turned down the offer, realizing that the British were trying to eliminate Orissa salt in order to maintain British salt at an artificially high price. But when the British had their offer rejected, they simply banned Orissa salt in Bengal. ${ }^{19}$

Since the border that Orissa shared with Bengal was a thick jungle, difficult to patrol, the first effect of the new ban was to create well-organized bands of salt smugglers. Inexpensive contraband salt from Orissa so flooded Bengal that the British salt still could not compete there. In 1803, in the name of fighting contraband, the British army occupied Orissa and annexed it to Bengal. ${ }^{20}$

On November $1^{\text {st }}, 1804$, by proclamation, Orissa salt became a British monopoly. The private sale of salt was completely prohibited. Those who had salt in their possession

\footnotetext{
${ }^{17} \mathrm{Ibid}$.

${ }^{18}$ Calvert, Albert F. (1915) Salt in Cheshire. New York: Spon and Chamberlain.

${ }^{19}$ Choudhury, Sadananda (1979) The Economic History of Colonialism: A History of British Salt Policy in Orissa. New Delhi: Inter-India Publications.

${ }^{20}$ Ibid.
} 
had to sell it to the government immediately at a fixed price. The transport of salt was forbidden. Even provisioning a ship with enough salt for the crew during a voyage had to be done under strict British supervision. Within ten years, it became illegal for salt to be manufactured by anyone other than the British government. A system of well-paid informant was established to prevent clandestine salt trading. ${ }^{21}$

The British advanced money to malangis against future salt production, and the malangis got deeper and deeper in debt and eventually were forced to work for the British producing salt to pay off their debt — virtual slaves to the British salt department. $^{22}$

In the early nineteenth century, to make the salt tax profitable and stop the smuggling, the East India Company established customs checkpoints throughout Bengal. In 1834, a zealous commissioner of customs, G.H. Smith, was appointed, and in his twenty years in office he expanded the system into a "Customs Line" around Bengal. Salt had to pay a duty to cross this line. He was able to get taxes dropped on a series of lesser items, including tobacco, so that customs officers could concentrate on salt smuggling. ${ }^{23}$ Customs officers were given that always disastrous combination of broad powers and low pay. They received bounties of confiscated salt and had unchecked authority to search, seize, and arrest. Not surprisingly, bribery and other forms of corruption were widespread. In the 1840 s, in its enthusiasm for enforcing this line, the East India Company constructed a fourteen-feet-high, twelve-feet-thick thorn hedge on the western side of Bengal to prevent the entry of contraband salt. After the British government took over following the 1857 "mutiny," as the uprising was labelled, the Customs Line grew

\footnotetext{
${ }^{21}$ Ibid.

${ }^{22}$ Ibid.

${ }^{23}$ Calvert, Albert F. (1919) Salt and the Salt Industry. London: Sir Isaac Pitman \& Sons.
} 
until it snaked arbitrarily 2500 miles across India from the Himalayas to Orissa. The hedge was expanded into a spiky gnarl of prickly pear, acacia, and more benign plants such as bamboo. It was impenetrable except for periodic gateways guarded by customs agents. By 1870, the Customs Line, largely dedicated to the enforcement of the salt tax, employed 12,000 people. $^{24}$

At first, having complete control, the British wanted to produce Orissa salt and sell it in Bengal at their prices. They cleared jungle land in the coastal region to extend the saltproducing area. But British salt merchants became concerned about competition for sales in the Bengal market and lobbied Parliament to repress salt production in Orissa. In 1836, duties on domestic production were made equivalent to duties on imported salt, and from then on the government did not care if salt was local or imported because it earned the same revenue on both. ${ }^{25}$

The local salt, fighting its way through a cumbersome and complicated bureaucracy, could not compete. It did not sell as fast and had to be stocked in warehouses near Calcutta and therefore risked being embezzled. The British colonial administration responded by limiting Orissa production, even closing some centres, saying that Orissa salt was of inferior quality and had a higher cost of production. In 1845 the colonial government ordered the annual production of salt to be reduced by an amount equal to half the previous year's total production. ${ }^{26}$ The commissioner of Orissa, A.J.M. Mills, wrote to the colonial administration warning that reducing salt production would turn the

\footnotetext{
${ }^{24}$ Choudhury, Sadananda (1979) The Economic History of Colonialism: A History of British Salt Policy in Orissa. New Delhi: Inter-India Publications.

${ }^{25}$ Ibid.

${ }^{26}$ Ibid.
} 
peasants of Orissa against the British, for in the salt areas the people knew of no other economic activity. ${ }^{27}$

Even in the hard times the Indian native malangis who lived in huts near the salt-fields lived hard lives. The British charged the malangis for any salt lost during transportation or from inadequate storage, even though transport and storage had nothing to do with salt workers. Salt agents tried to impress on the imperial British government the need to raise payments to salt makers, but instead the imperial government, wishing to discourage production, periodically lowered the rate. ${ }^{28}$

The British policy was to preserve the jungles near the salt lands as sources of fuel wood. Since these forests had been reduced to clear land for salt production, they had an unusual concentration of tigers, bears, and leopards, and eventually the malangis were so terrified of the jungle that many refused to enter to cut fuel. In the 1846 season alone, twenty-two malangis were killed by tigers. The salt and the revenue departments both offered rewards for the heads of wild animals. Though the reward was considered substantial, it did not produce enough kills to significantly reduce the wildlife. ${ }^{29}$

In 1863, the British government announced its intention to stop local salt production and instructed salt agents to end salt manufacture as soon as possible. The abandonment of salt manufacture led to a famine in Orissa in 1866. The greatest loss of life in the famine was among the malangis, because they had no crops of their own to fall back on for food. Government policy also caused a salt shortage in Bengal. ${ }^{30}$

The British responded to the crisis by starting their own plant to make kartach salt. The object was to furnish locals with cheap salt while providing them with jobs. It was so

${ }^{27}$ Ibid.

${ }^{28}$ Ibid.

${ }^{29}$ Ibid.

${ }^{30}$ Ibid. 
successful that Liverpool salt could not compete, and so, in 1893, the government closed down the plant. Outperforming British salt was against the rules. ${ }^{31}$

Once the plant was closed down, the malangis starved, while salt, their traditional cash crop, was lying at their feet in sparkling crusts, waiting to be picked up and sold. But even scrapping salt off the surface of the flats was a severely punishable offence.

The people of Orissa were forbidden from any activity connected with salt making. They left their starving wives and children and went to other parts of India looking for work, living in crowded, unsanitary conditions as they struggled to earn enough from menial labour to send some money to their families. In time, the malangis disappeared from Orissa, and anyone there who was poor was now deprived of salt. ${ }^{32}$

On March 12, 1930, Gandhi and approximately 78 male Indians set out, on foot, for the coastal village of Dandi some 240 miles from their starting point in Sabarmati, a journey which was to last 23 days $^{33}$. Virtually every resident of each city along this journey watched the great procession, which was at least two miles in length. ${ }^{34}$ On April 6th he picked up a lump of mud and salt and boiled it in seawater to make the commodity which no Indian could legally produce - salt. ${ }^{35}$

He implored his thousands of followers to begin to make salt wherever, along the seashore, "was most convenient and comfortable" to them. A "war" on the salt tax was continued during the following weeks. Salt was sold, illegally, all over the sea-coast of India. A pinch of salt from Gandhi himself sold for 1,600 rupees (approximately $\$ 750$ at

\footnotetext{
${ }^{31}$ Ibid.

${ }^{32}$ Ibid.

${ }^{33}$ Jack, Homer A. The Gandhi Reader: A Source Book of His Life and Writings. Bloomington: Indiana University Press, 1956. p. 237.

${ }^{34}$ Ibid. p. 237.

${ }^{35}$ Ibid. p. 240.
} 
the time.) In reaction to this, the British government had incarcerated over sixty thousand people at the end of the month. ${ }^{36}$

Soon thereafter one night, when Gandhi was sleeping, he was apprehended at midnight by heavily-armed forces under a regulation of 1827 . The effects of the salt march were felt across India. Thousands of people made salt, or bought illegal salt. This period is to be considered the apex of Gandhi's political appeal, as the march mobilized many new follwers from all of Indian society and the march came to the world's attention. After Gandhi's release from prison he continued to work towards Indian independence, which was achieved in August, 1947, but Dandi was a key turning point in that struggle.

According to Albert Hirschman (1970) ${ }^{37}$ individuals express their preferences by three distinct processes of exit, voice and loyalty. A necessary condition for the effective use of the exit option is full mobility (free entry and exit) of buyers and sellers to promote market efficiency. Under an imperial regime of confiscatory salt taxation, such mobility did not exist. Since the boundaries of the polity are predefined and inclusive, the citizenry is fixed. As there is no political process within an imperial order, the citizenry have no choice to voice their concern. Neither can the citizenry leave the extractive imperial state to avoid the consequences of its decisions. Given the assumptions of fixed boundaries and imperial citizenship in an extractive state, the characteristics of a pure public good, nonexcludability and jointness of supply, required that a collective voice or non-market decision process be used to reveal individual preferences in order to achieve Pareto

\footnotetext{
${ }^{36}$ Ibid. p. 240-243.

${ }^{37}$ Albert O. Hirschman (1970) Exit, Voice and Loyalty. Cambridge, MA: Harvard University Press.
} 
efficient outcome, as Samuelson (1954) emphasized ${ }^{38}$. The Gandhian strategy of civil disobedience was a manifestation of this necessity. "The rules of the Prisoners' Dilemma create an environment that is inimical for rational cooperation and, just as one cannot reasonably expect someone to juggle successfully with his hands tied behind his back, so one cannot expect rational agents in cooperating when constrained by the rules of the Prisoners' Dilemma"39 (Binmore 1994).

A colonized person could have been given one preference ordering, and as and when the imperial extractive needs of the colonizer might have arose or changed, this was supposed to reflect the colonized person's interests, represent his welfare, summarize his idea of what should be done, and describe his actual choices and behaviour. Can one preference ordering for the colonized person do all these things? A policy of colonization thus described may be 'rational' in the limited sense of revealing no inconsistencies in the choice behaviour of the colonizer imposed on the colonized person, but if the colonizer has no use for these distinctions between different concepts of preference ordering, he must be a bit fool. The purely economic colonizer like Amartya Sen's purely economic man is indeed close to being a social moron ${ }^{40}$ (Sen 1977).

\section{Identity and Cognitive Dissonance - Ethnic Capital Formation and the Logic $\underline{\text { of Collective Action }}$}

The construction of a nation or a homeland for an imagined community is a collective good in the sense that "other individuals in the group cannot be kept from

\footnotetext{
${ }^{38}$ Samuelson, Paul A. (1954) "The Pure Theory of Public Expenditure" Review of Economics and Statistics 36.

${ }^{39}$ Binmore, Kenneth (1994) Game Theory and the Social Contract. Vol. I. Cambridge: MIT Press. p. 103.

${ }^{40}$ Sen, Amartya, (1976-77), "Rational Fools: A Critique of the Behavioural Foundations of Economic

Theory," Philosophy and Public Affairs, No. 6, 1976-7, pp. 99.
} 
consuming it once any individual in the group has provided it for himself." ${ }^{\text {"1 }}$ The corollary to this general conclusion is that a collective good can be provided only if it is seen as a private good by the actor. A person's identity or his sense of self is his private good (Akerlof and Kranton 2000). The collective action literature teaches us that situations characterized by collectively supplied benefits and privately incurred costs will not motivate participation in collective endeavors. Therefore additional incentives are needed to move the potential participants into action. In other words, the leaders of an independence movement need to be able to present their objective worth pursuing for its own sake and be able to provide additional incentives simultaneously in the form of reputation enhancing private rewards. One particularly effective way to provide an individual with a reputation enhancing private reward is to supply an identity based ethnic reputational reward. Ethnic reputational rewards can be the basis for political exchange in collective action and investments in ethnic networks can subsequently serve as ethnic capital (Wintrobe 1992). The crucial feature of ethnic capital is the uniqueness of ethnic identity as a basis for network "membership." To the extent that this criterion is used, entry and exit from the ethnic network is blocked for a generation. Since identity based ethnic capital cannot move from one group to another, it follows that competition among ethnic groups does not equalize returns among them. Consequently, differences in returns and therefore in incomes persists. If there are two distinct ethnic groups, one representing the colonizer and the other representing the colonized, the income differential between the colonizer and the colonized creates cognitive dissonance ${ }^{42}$ for the colonized. Since there can be no competition between the ethnic group of the colonizer

\footnotetext{
${ }^{41}$ Olson, Mancur (1965) The Logic of Collective Action: Public Goods and the Theory of Groups, Cambridge, MA: Harvard University Press. P. 35.

42 Akerlof, George A. (1982) and Dickens William. "The Economic Consequences of Cognitive Dissonance” American Economic Review Vol. 72. pp. 307-317
} 
and the ethnic group of the colonized to equalize returns, the social and political value of the colonizer's identity based ethnic capital will always remain artificially and discriminately higher than the social and political value of the ethnic capital of the colonized, the economic consequences of who's cognitive dissonance ${ }^{43}$ cannot be ignored by any other means but subversive collective actions of strategic non-violent forms.

In the communitarian 'constitutive' conception of an ethnic community (Sandel 1998, Sen 1999) identity comes before reasoning for choice: "the self came by its ends, not by choice but by reflection, as knowing (or inquiring) subject to object of (self-) understanding." ${ }^{44}$ Therefore, "a person's identity is something he or she detects, rather than determines. ${ }^{45}$ Social organization can then be seen as attempts to "create opportunities for men and women to give voice to what they have discovered about themselves and the world and to persuade others of its worth" ${ }^{, 46}$ If the social organization of the British Empire in India can be seen as attempts to create opportunities for English men and women to give voice to what they believed to have discovered about themselves and the world around them - a "civilizing" belief that England should assist in the development of "backward peoples" towards greater refinement, just as the early Romans were believed to have brought civility to England, ${ }^{47}$ it became a necessary cognitive dissonance reduction strategy ${ }^{48}$ of the colonized people to invest in ethnic networks to produce identity based ethnic capital for distribution as private reputational rewards

\footnotetext{
${ }^{43} \mathrm{Ibid}$

${ }^{44}$ Sandel, Michael (1998) Liberalism and the Limits of Justice, $2^{\text {nd }}$ ed. Cambridge: Cambridge University Press. p. 150. Quoted by Sen, Amartya K. (1999) Reason Before Identity. Oxford: Oxford University Press. p. 17. 
within the members of their ethnic community. This special reward was contingent upon actual participation in the independence movement. Participation, in short, is a necessary and sufficient condition for being rewarded with an extra private reputational good - an extra reputational benefit to flow to a participant who joins the collective action movement. A potential participant who does not join the independence movement receives no extra reputational benefit. Such selective incentives in the form of reputational benefits are always defined as private goods or side payments that are available to potential participants who participate in the independence movement. Participants in an independence movement thus receive multiple payoffs for their contributions: divisible and excludable private reputational rewards as well as nondivisible and nonexcludable public goods.

\section{The Model:}

Consider a group of $N$ symmetric players (Indians of Colonial British India).

Benefits and costs depend on the number of active (nationalist-Indian) players:

When there are n participants, every player gets gross benefits $\quad b(n), b>0$

participants incur costs of $c(n)$ each.

Thus, every participant gets the payoff: $\quad p(n)=b(n)-c(n)$.

Each non-participant/free-rider/shirker gets $s(n)=b(n)$.

The decision whether to participate or to shirk depends of course on what the others are doing. They consist of $\mathrm{n}$ participants and $(N-1-n)$ shirkers.

Thus if you shirk you get $s(n)$ and if you participate you get $p(n+1)$.

Implying you shirk if $s(n)>p(n+1)$, you participate if $s(n)<p(n+1)$ 
We can now construct a Collective Action game in general form for the 2 players' case:

\begin{tabular}{|c|c|c|}
\hline & PARTICIPATE & $\begin{array}{c}\text { NOT } \\
\text { PARTICIPATE }\end{array}$ \\
\hline PARTICIPATE & $p(2), p(2)$ & $p(1), s(1)$ \\
\hline $\begin{array}{c}\text { NOT } \\
\text { PARTICIPATE }\end{array}$ & $s(1), p(1)$ & $s(0), s(0)$ \\
\hline
\end{tabular}

Where the total payoff for the Colonial Indian society in terms of collective welfare

would be: $T(n)=n \cdot p(n)+(N-n) \cdot s(n)=N s(n)-n[s(n)-p(n)]$

Now Consider the Right hand side:

$1^{\text {st }}$ term: increasing because $s=b>0$

Therefore, it all depends on the $2^{\text {nd }}$ term, i.e., a shirker's or free-rider's extra pay-off:

$$
[s(n)-p(n)]
$$

If it is small and does not increase heavily, welfare is maximized at:

$$
n=N \quad \text { => Prisoner's Dilemma I, Chicken I (Assurance). }
$$

If it is heavily increasing, welfare is maximized at:

$$
n<N=>\text { Prisoner's Dilemma II, Chicken II }
$$

\section{Observe:}

1) For all $n \leq N-1: s(n)>p(n+1)$, shirking from participation is the best response independently from $n$, i.e., Nash Equilibrium at $n=0$

2) $s(0)<p(n)$ : everybody contributing is strictly preferred => Prisoner's Dilemma.

3) Yet, collective welfare not necessarily max at $n=N$, since it depends on $T(n)$ if the shirker's extra payoff is small and increases not too heavily $=>$ Prisoner's Dilemma I, otherwise Prisoner's Dilemma II. 
Now consider the Chicken case:

\section{Observe:}

1) For small $n: s(n)<p(n+1) \Rightarrow$ participation is the best response.

2) For large $n: s(n)>p(n+1) \Rightarrow$ shirking from participation is the best response.

With (1) and (2) together, Nash equilibrium is at $n>0$.

3) $p>0$ is not necessary.

4) If collective welfare is maximized at $n=N$, then Chicken I.

5) Yet, if collective welfare is maximized at $n<N$, then, $n=n$ only accidentally.

\section{Minor problems:}

1) Intersection is not necessarily at an $n$.

2) $n$ separates shirkers and participants.

3) The problem of the 2-player case remains: Who are the chickens?

\section{Possible solutions:}

(1) Leadership by strong social, religious and political charismatics such as Mahatma Gandhi.

(2) The strong players (nationalist-Indians) participate, while the weak players (weak-nationalists) ride free.

\section{Observe:}

1. for small $n: s(n)>p(n+1) \Rightarrow$ shirking from participation is the best response.

2. for large $n: s(n)<p(n+1) \Rightarrow$ participation is the best response.

3. Taking both (1) and (2) in consideration, there are 2 Nash equilibria,

$$
\text { at } n=0 \text { and at } n=N \text {. }
$$

Yet, how likely is the good equilibrium in large groups? 
1) If $\mathrm{N}$ is large a single player decision has only very little effect on overall payoff:

$$
p(n+1) \approx p(n)
$$

But, $p(n)=b(n)-c(n)<b(n)=s(n)$

i.e. shirking from participation is always the best response.

Expect for every game: a prisoner's dilemma if $N$ is sufficiently large.

\section{Strategic Civil Disobedience and All-or-Nothing Public Goods}

In the Logic of Collective Action, Olson (1971, 43-65) suggested that small groups would more easily cooperate than large groups in supplying themselves with public goods. Large groups are more difficult and costly to organize. Individual decisions are less likely to have an impact on the outcome of collective action, and each member receives a smaller share of the total benefits of the collective good. In general, creation of interdependence among individual actors plays a critical role in favourably resolving the prisoner's dilemma for the group as a whole as modelled above.

The special kind of public good, known as an "all-or-nothing" good, requires unanimous support to be produced (Laver, 1981). Since collective goods of this sort will be destroyed by a single defection, it is in the self-interest of each person to pay his share of the total cost: to opt for a free ride under the circumstances would make not only the others worse off but himself as well. Such goods no longer present a prisoner's dilemma to the group; instead, as shown in the following figure, each individual is best served if he coordinates his actions with the actions of others. Moreover, between total defection and total cooperation, everyone prefers $\mathrm{CC}$ to $\mathrm{DD}$, since the value of the public good exceeds anyone's share of its cost. More importantly, given the all-or-nothing characteristic of the 
public good, no one has an incentive to free ride. For these reasons, group members ought to be able to coordinate their actions to produce the best outcome.

GROUP

\section{INDIVIDUAL}

\begin{tabular}{|c|c|c|}
\hline & C & D \\
\hline C & $\begin{array}{c}\text { Public Good }- \\
\text { Cost }\end{array}$ & $\begin{array}{c}\text { No Public } \\
\text { Good - Cost }\end{array}$ \\
\hline D & $\begin{array}{c}\text { No Public } \\
\text { Good }\end{array}$ & $\begin{array}{c}\text { No Public } \\
\text { Good }\end{array}$ \\
\hline
\end{tabular}

All-or-nothing goods enjoy a property known as "pure jointness of production": they depend on the cooperation of everyone. Typically, individual contributions not only are not pivotal, they have no discernible effect. Nevertheless, we should find that where pure jointness of production pertains, the public good will be more easily generated.

Furthermore, collective action problems may sometimes be solved using measures that create pure jointness of production. Mahatma Gandhi and the masterminds behind the strategic civil disobedience in India shrewdly reframed the objectives of their non-violent protest against the British taxation of salt so that individual participation was critical. Successful leaders like Mahatma Gandhi encouraged cooperation, by breaking up a large goal into many steps with critical thresholds. If a large goal can be broken into many small independent pieces, all of which are necessary to the larger goal, the free-rider problem can be overcome, for if each person has a monopoly on a necessary factor for the final good, all contributions are essential.

It will not always be apparent to group members that they are pursuing an all-ornothing good. For this reason, effective leadership and organization often will still be critical to the success of collective action, but the task of deterring free ridership will be 
eased in such cases. The successful production of certain public goods, therefore, will depend on whether or not people think the good must be jointly produced.

\section{Cascading Civil Disobedience, Movement-Spillover, Positive Network Externalities and the Iterative Prisoner's Dilemma:}

Social identity is complex because individuals participate in many groups; they themselves act as bridges, not across geographical distance, but across conceptual distance. "Social identity, therefore, exhibits a multidimensional nature -individuals spanning different social contexts...."49 Affiliation, like bridging, reduces distance. This renders network effects almost impossible to trace. Information can leap from group to group even when those groups seem to have nothing in common, because all they need in common is a single individual who is a member of both groups and therefore has a bridging identity. For the movement of the independence of India, Mahatma Gandhi provided such a bridging identity. The structure and identities of agents in social networks determine the network's threshold with regards to effects that cascade throughout part or the entire network. Agents have their own thresholds as well, but network connectivity is what makes cascades possible. For instance, in epidemiology, a highly clustered social network works against the rapid spread of infection because individuals have contact primarily with those who are already infected. Similarly, it is the same social network that renders civil disobedience to achieve economic and political independence in an identical way. In addition, an agent who is neither susceptible to the disease nor the movement of civil disobedience, has less chance and possibly no chance of becoming either infected by the disease or the movement of civil disobedience. "The possibility of a (social) epidemic (of civil disobedience) depends on the existence of what

\footnotetext{
${ }^{49}$ D. J. Watts, Six Degrees: The Science of a Connected Age, New York: W.W. Norton, 2003, p. 151.
} 
has been called a percolating cluster - a single cluster of susceptible sites... that permeates the entire population" ${ }^{, 50}$, in other words, a chain of interconnected nodes which connects the entire rest of the network. An identical analysis is possible with respect to the spread of ideas, or memes and behaviour in the context of civil disobedience.

Social networks utilize threshold models of decision making that take into account two factors: the number of connections, and their weight, or likelihood of influence. Paralleling Complexity's "edge of chaos," individuals are poised between too few connections and too many. Too few connections and an individual is less likely to be influenced, but counter-intuitively too many connections produces the same result because the relative influence of each connection is smaller. In addition, individuals, in general, are more influenced by those socially "near" to them than by those that are socially "distant." Nonetheless, how an individual's threshold is calculated is irrelevant, since once it has been crossed, it may have repercussions for the population as a whole. Because social bridges reduce "distance" between clusters, they increase the "closeness" of all nodes, and thus, increase the likelihood that they will have an influence. This provides a mechanism for the reinterpretation involved in creating Rosenau's "localized phenomena." ${ }^{51}$ It is important to realize that there are in effect two thresholds operating simultaneously: the individual's threshold which is similar to his "susceptibility" and the network's threshold which is a function of connectivity. Once these thresholds are crossed, the network becomes vulnerable to cascades. "Networks of social information," Watts tells us, "are important not just because they help us to make better individual decisions but also because they allow things that have caught on in one setting to spill over into another. Since this kind of spillover is critical to the dynamics of a cascade,

\footnotetext{
${ }^{50}$ K. N. Waltz, Theory of International Politics, Boston, Mass.: McGraw-Hill, 1979. p. 185.

${ }^{51}$ Rosenau, James N (2003) Distant Proximities: Dynamics Beyond Globalization. Princeton, N.J.: Princeton University Press. p. 45.
} 
(e.g. Bikhchandani, Hirschleifer and Welch, 1998) social networks are central to the notion of a little thing becoming big" ${ }^{92}$, just as we witnessed how a carefully crafted protest against taxation of salt transformed itself into a full blown nationalist independence movement in the days following Gandhi's salt march to Dandi. Furthermore, thresholds behave similarly "with cultural fads, technological innovations, and political revolutions such as the movement of civil disobedience, cascading crises, and other manners of collective madness, mania, and mass action. The trick is to focus not on the stimulus itself but on the structure of the network that the stimulus hits" ${ }^{, 53}$. Again, the danger is in looking for "causes" because "contingent decision making comprises the essence of an information cascade, and in so doing renders the relationship between initial cause and ultimate effect deeply ambiguous" ${ }^{, 54}$.

Therefore, as we witnessed in Gandhi's salt march in the past, civil disobedience is mobilized through networks. Networks tend to diffuse. Diffusion processes produce cycles or waves or action and thereby making the networks important to diffusion. However, there is considerable ambiguity about the relationship among networks, diffusion, and action cycles and the way these can be identified in empirical data. Unpacking the "network" concept into different kinds of processes can reveal how these different network processes affect the diffusion process in civil disobedience. We conceive the movement of civil disobedience as a diffused action field in which actions affect other actions and the action repertoires of the different actors co-evolve through time and through interaction with each other. Civil disobedience activists and the repressive British imperial regime engage in strategic interactions, each responding to the actions of the other. Different organizations within the civil disobedience movement

\footnotetext{
52 Ibid 229.

53 Ibid., p. 249.

${ }^{54}$ Ibid., p. 246.
} 
respond to the actions of others, as successful tactical innovations and movement frames diffuse to new organizations. News media cover or fail to cover particular protests, and thus encourage or discourage future protests. Each of these processes affects the others, in a complex, multi-faceted set of interactions. Over time, the action set of each actor evolves in response to the actions of the others and, thus, the whole field is one large co-evolving environment in which the characteristics and actions of any actor is constrained and influenced by the characteristics and actions of all other actors in the environment. Therefore, strategic interactions between movements of civil disobedience and imperial regimes may be understood as a co-evolutionary process where the dynamics of protest waves or cycles are driven by the interplay between imperial regimes and colonial dissidents.

Social turmoil comes in waves (e.g. Banerjee 1992). Much of the broad theoretical synthesis of what we call civil disobedience can be recast in diffusion terms. Tactical diffusion showed that the strategy of civil disobedience of Mahatma Gandhi was not a steady stream, but a series of bursts of action each driven by a tactical innovation:

Marching to protest against salt taxation; picking up salt from the sea against the imperial salt law; selling the same salt in violation of the salt law; encouraging the masses of India to repeat infinitely the salt making process. Over time one social movement affects another, as tactics and frames diffuse and produce the effects what Meyer and Whittier (1994) call "movement spillover." ${ }^{55}$ As a result of this positive network externality of movement-spillover, the problem of civil disobedience takes on a new feature due to the fact that the contributors to the public good now have ongoing social ties. Ongoing social interaction is much better modelled by a serial or iterated prisoner's dilemma game than

55 Meyer, David S., and Nancy Whittier (1994) “Social Movement Spillover.” Social Problems 41:277-298 
by a single-play game. When there is optimal social linkage through a common cause of civil disobedience, each individual's repeated interaction with each of his compatriot against a colonial oppressor creates spillovers. Each individual's discount factor gets determined randomly and each individual then plays a repeated prisoner's dilemma game to implement the agenda of civil disobedience. A local trigger strategy equilibrium (LTSE) can be used to describe an equilibrium in which each individual conditions his cooperation on the cooperation of at least one acceptable group of compatriots. ${ }^{56}$ For example, an individual living on a particular block of a certain neighbourhood may choose to participate in the civil disobedience movement as long as either of his adjacent neighbours continues to do so. However, if both neighbours ever choose not to participate in the civil disobedience movement, then the individual permanently reverts his behaviour by not participating.

It is well known that repeated game can mitigate the free-rider problems when such social spillovers exist. Under these circumstances, one's rational strategy is less apparent than in the single play prisoner's dilemma. If there is only one play (or one exchange), each player is better off defecting no matter what course of action is pursued by his opponent, since defection is a "dominant" strategy in the game. While the outcome in the case of mutual defection, ironically, is not Pareto optimal or "collectively rational," this does not make each player's strategy any less individually rational. Only when the game is iterated does each player have an incentive and an opportunity to reach a more profitable collective solution. People who distrust each other therefore can promote cooperation by committing themselves to multiple exchanges. That is why the vast majority of both Hindu Indians and Muslim Indians were found to participate jointly in

${ }^{56}$ Haag, Matthew \& Lagunoff, Roger (2004) "Social Norms, Local Interaction, and Neighborhood Planning" Working Paper, Georgetown University. 
the movement of civil disobedience to bring an end to the British Empire in India in response to the call of Mahatma Gandhi. According to $\operatorname{Hardin}^{57}$ (1982) there will always be a possibility that cooperative conventions will be formed when a prisoner's dilemma is played an indefinite number of times. In principle, the indeterminacy of the number of iterations is critical, since this means that the participants are unaware of when the last game will be played. Conversely, if the exact number of plays were known to the participants, they would approach the last game in the same way they would approach any single play prisoner's dilemma. As a result, contingent strategies (which assume future encounters) would be abandoned and both players would approach any single play as if it were the last. This observation by Hardin proved to be critical for India when the civil disobedience movement of Mahatma Gandhi's leadership faced a historical crisis when the Indian-Muslims were determined to have a separate state for the Muslims in the event of the independence of India. This issue (that is beyond the scope of this paper) added a single play attribute to the iterative prisoner's dilemma game of civil disobedience.

\section{Conclusion}

Any public spirited movement of civil disobedience resembles an assurance game in which potential activists will only participate if they can be confident that enough other activists will also participate to make their efforts worthwhile. Since spontaneous mass coordination does not occur, dedicated leadership must be provided along with examples of symbolic and tangible successes so that veteran activists will stay the course and new ones join the course to ensure pure jointness of production of the all-or-nothing public

\footnotetext{
${ }^{57}$ Hardin, Russell (1982) Collective Action. Baltimore: Resources for the Future/Johns Hopkins University Press.
} 
good of civil disobedience. Mahatma Gandhi's march to protest salt taxation, and a pinch of salt from Gandhi himself that sold for 1,600 rupees ( $\$ 750$ dollars at the time), had been such a symbolic and tangible success that resulted in cascading civil disobedience in ushering the independence of India. The model that incorporates this dynamic of cascading civil disobedience is a process of supply and demand that depicts how the individual decisions to join or quit a movement translate into collective outcomes. It also depicts how the dynamic of the movement changes over time. An advantage of this type of model is that it allows us to trace the separate and combined effects of a number of key factors or parameters on the development of a social movement. By making different assumptions about the relative values of the parameters - that is by varying theoretically the rate of oppressor's responsiveness, the strength of social networks and organizations, and other factors - numerous deductions can be offered about how these changes will affect the course of the movement over time. Another strength of dynamic models is that the mathematical theory underlying them allows us to specify precisely the equilibrium and stability conditions of the system under consideration. Given any set of assumptions about the parameters of the model, we can establish the equilibrium of the dynamic system as well as whether the equilibrium will be realized.

To model the dynamics of strategic civil disobedience, we need to add to our model a term that measures the goals and the accomplishments of the civil disobedience participants. When this difference is large, members of the aggrieved group have a strong incentive to engage in civil disobedience. When it is small, the motivation to participate in the civil disobedience movement is appropriately reduced. Therefore the utility function of the oppressor is maximized at a point when this difference is the lowest. 
Therefore consider that in every time period there are some problems that emerge, or, more subjectively, are identified or defined by political leaders and targeted for solution. In conjunction with these problems, demands are formulated which accumulate if unmet and dissipate if satisfied. These are not necessarily all of the problems and demands of the group; rather, we should think of a subset of group's grievances which for one reason or another (e.g., because they have clear solutions, because there is group agreement about how to address the problem, because they are highly symbolic) are capable of inspiring and sustaining collective action. Therefore, as stated previously, by articulating the demands of the movement, political leaders give direction and a sense of purpose to the rank and file.

If $D$ represents the constant or basic amount of demand that is formulated in every time period and $S(t)$ is the level of supply in period $t$, then in the course of $T$ periods, the difference between the amount supplied and the amount demanded equals:

$\sum_{\mathbf{t}=1}^{T}(S-D)$

Intuitively, if this sum is negative, civil disobedience should be stimulated, and if it is positive, activism should be dampened. A group that has been neglected for a long time will require more concessions before it is placated than a group that has been catered to within the political process. I should note here that there of course need not be any constant amount of demand added in each period; it is merely a simple initial assumption in the model. However, the dynamics of the model is significantly affected if the number of demands formulated per period diminishes with time. The inability of the leaders of the movement to formulate new demands which could inspire civil disobedience can help 
to precipitate the rapid decline of the movement. These are understandable in terms of rational and strategic positions in which the rules place individuals.

\section{REFERENCE}

1. Acemoglu, Daron (2003). "Why Not a Political Coase Theorem? Social Conflict, Commitment and Politics," Journal of Comparative Economics, 31, 620-652.

2. Acemoglu, Daron and James Robinson (2000). "Political Losers As a Barrier to Economic Development" American Economic Review Papers and Proceedings, vol 90, 126-130.

3. Acemoglu, Daron, James A. Robinson and Simon Johnson (2001) "The Colonial Origins of Comparative Development: An Empirical Investigation.” American Economic Review, volume 91, pp. 1369-1401.

4. Acemoglu, Daron, James A. Robinson and Simon Johnson (2002) "Reversal of Fortune: Geography and Institutions in the Making of the Modern World Income Distribution.” Quarterly Journal of Economics, Volume 117, pp. 1231-1294.

5. Agarwal, S.C. (1976) The Salt Industry in India. New Delhi: Government of India Press.

6. Akerlof George A. and Kranton Rachel E. (2000) "Economics and Identity." Quarterly Journal of Economics, Volume CXV, pp. 715-753

7. Akerlof, George A. (1982) and Dickens, William. "The Economic Consequences of Cognitive Dissonance" American Economic Review Vol. 72. pp. 307-317. 
8. Albert O. Hirschman (1970) Exit, Voice and Loyalty, Cambridge, MA: Harvard University Press.

9. Axelrod, Robert (1985), The Evolution of Cooperation. New York: Basic Books.

10. Banerjee, Abhijit (1992). "A Simple Model of Herd Behaviour." Quarterly Journal of Economics, vol. 107(3), p. 797-817.

11. Banerjee, Abhijit (1997). "A Theory of Misgovernance." Quarterly Journal of Economics, vol. 112(4), p. 1289-1332.

12. Bannerjee, Abhijit and Lakshmi Iyer (2002). "History, Institutions and Economic Performance: The Legacy of Colonial Land Tenure Systems in India." Mimeo.

13. Becker, Carl (1931) Annual Address of the President of the American Historical Association, delivered at Minneapolis. December 29, 1931. Reprinted in the American Historical Review, Volume 37(2), p. 221-236

14. Bikhchandani Sushil, Hirshleifer Jack and Welch, Ivo (1998) "Learning from the Behaviour of Others: Conformity, Fads and Informational Cascades" Journal of Economic Perspective. Volume 12(3). p. 151-170

15. Bridbury, A.R. (1955) England and the Salt Trade in the Later Middle Ages. Oxford: Oxford University Press.

16. Calvert, Albert F. (1915) Salt in Cheshire. New York: Spon and Chamberlain.

17. Calvert, Albert F. (1919) Salt and the Salt Industry. London: Sir Isaac Pitman \& Sons.

18. Chong, Dennis (1991), Collective Action and the Civil Rights Movement, Chicago: University of Chicago Press. 
19. Choudhury, Sadananda (1979) The Economic History of Colonialism: A History of British Salt Policy in Orissa. New Delhi: Inter-India Publications.

20. Coase, Ronald (1937) “The Nature of the Firm," Economica, 4(16), 386-405.

21. Coase, Ronald (1960) “The Problem of Social Cost," Journal of Law and Economics, III, 1-44.

22. Condorcet, J.A (1795) Sketch for a History for the Progress of the Human Mind. Connecticut: Hyperion Press, 1979.

23. Colley, Linda (1994) Britons. New Haven: Yale University Press.

24. Crowley, B. (1987) The Self, the Individual, and the Community. Oxford: Oxford University Press.

25. Diamond, J. (1997), Guns, Germs, and Steel. W.W. Norton and Co., New York.

26. Engerman, Stanley and Kenneth Sokoloff (2002) "Factor Endowments, Inequality, and Paths of Development Among New World Economies, NBER Working Paper \# 9259.

27. Engerman, Stanley, and Kenneth, Sokoloff (1997) "Factor Endowments, Institutions and Differential Paths of Growth among New World Economies: A View from Economic Historians of the United States," in How Latin America Fell Behind, edited by Stephen Haber, Stanford University Press.

28. Engerman, Stanley, and Kenneth, Sokoloff (2000) "Institutions, Factor Endowments, and Paths of Development in the New World" Journal of Economic Perspectives, Volume 14(3), p. 217-32. 
29. Grossman, Sanford and Oliver Hart (1986) "The Costs and Benefits of Ownership: A Theory of Vertical and Lateral Ownership,” Journal of Political Economy, 94, 691-719.

30. Haag, Matthew \& Lagunoff, Roger (2004) "Social Norms, Local Interaction, and Neighborhood Planning" Working Paper, Georgetown University.

31. Hardin, Russell (1982) Collective Action. Baltimore: Resources for the Future/Johns Hopkins University Press.

32. Hardin, Russell (1997) One for All: The Logic of Group Conflict. Princeton: Princeton University Press.

33. Hobbes, Thomas (1660) Leviathan. edited by: J.C.A. Gaskin (Oxford: Oxford University Press, 1996).

34. Hobsbawm, Eric J. (1992) Industry and Empire. New York: Viking Press.

35. Jack, Homer A. (1956) The Gandhi Reader: A Source Book of His Life and Writings. Bloomington: Indiana University Press.

36. K. N. Waltz (1979) Theory of International Politics, Boston, MA: McGraw-Hill.

37. LaPorta (1998), F. Lopez-de-Silanes, A. Shleifer, and R. Vishny, "Law and Finance," Journal of Political Economy, 106(6), December 1998;

38. LaPorta (1999), R., Lopez-de-Silenas, F., Shleifer, A. and Vishny, A., “The Quality of Government", Journal of Law, Economics and Organization, V.15, p.222-279. 
39. LaPorta (2000), F. Lopez-de-Silanes, A. Shleifer, and R. Vishny, "Investor Protection and Corporate Governance," Journal of Financial Economics, October, 2000.

40. Laver, Michael (1981) The Politics of Private Desires. New York: Penguin Books.

41. Lichbach, Mark Irving (1995) The Rebel's Dilemma. Ann Arbor, MI: Unversity of Michigan Press.

42. Lichbach, Mark Irving (1996) The Cooperator's Dilemma. Ann Arbor, MI: Unversity of Michigan Press.

43. McNeill, W.H. (1976), Plagues and Peoples. Anchor Books, New York.

44. Meyer, David S., and Nancy Whittier (1994) "Social Movement Spillover." Social Problems 41:277-298

45. Mullainathan, Sendhil (2002) “A Memory-Based Model of Bounded Rationality," Quarterly Journal of Economics, 117, (3), p. 735-774

46. North, Douglas C. (1981) Structure and Change in Economic History, W.W. Norton \& Co., New York.

47. North, Douglas C. (1990) Institutions, Institutional Change and Economic Performance, Cambridge University Press, New York.

48. North, Douglas C. (1991), "Institutions, Transaction Costs and the Rise of Merchant Empires", in Tracy, J. D. ed., The Political Economy of Merchant Empires.

49. Olson, Mancur (1965) The Logic of Collective Action: Public Goods and the Theory of Groups, Cambridge, MA: Harvard University Press. 
50. Ostrom, Eleanor (1990) Governing the Commons. Cambridge: Cambridge University Press, 1990.

51. Rosenau, James N (2003) Distant Proximities: Dynamics Beyond Globalization. Princeton, NJ: Princeton University Press.

52. Roy, Moxham (2001) The Great Hedge of India. London: Constable.

53. Samuelson, Paul A. (1954) “The Pure Theory of Public Expenditure” Review of Economics and Statistics 36.

54. Sandel, Michael (1998) Liberalism and the Limits of Justice, $2^{\text {nd }}$ ed. Cambridge: Cambridge University Press.

55. Schumpeter, Joseph A. (1918) "Crisis of the Tax State” in Swedberg, R. (1991) The Economics and Sociology of Capitalism. Princeton, NJ: Princeton University Press.

56. Selten, Reinhard and Reinhard Tietz (1980). “Zum Selbstverstandnis der experimentellen Wirtschaftsforschung im Umkreis von Heinz Sauermann. (An Inside View of Experimental Economics in the Vicinity of Hans Sauermann. With English summary.)," Z. ges. Staatswiss, 136:1 (March), 12-27.

57. Sen, Amartya K. (1999) Reason Before Identity. Oxford: Oxford University Press.

58. Simon, Herbert A. (1957) Models of Man. New York: John Wiley \& Sons.

59. Simon, Herbert A. (1982) Models of Bounded Rationality. Cambridge, Mass: MIT Press. 
60. Tarrow, Sydney (1998) Power in Movement: Social Movements and Contentious Politics. 2nd ed. Cambridge: Cambridge University Press.

61. Thoreau, Henry David (1951) Cape Cod. New York: Bramhal House.

62. Watts, D.J. (2003) Six Degrees: The Science of a Connected Age, New York: W.W. Norton.

63. Williamson, Oliver (1975) Markets and Hierarchies: Analysis and Antitrust Implications, New York: Free Press.

64. Williamson, Oliver (1985) The Economic Institutions of Capitalism, New York: Free Press.

65. Wintrobe, Ronald (1992) "Some Economics of Ethnic Capital Formation and Conflict”, in Breton, Albert. ed., Nationalism and Rationality. Cambridge: Cambridge University Press. 